\title{
MICROBIOLOGY AND PHYSICOCHEMICAL PROPERTIES OF MECHANIC WORKSHOP POLLUTED SOIL AMENDED WITH COWPEA CHAFF IN ANYINGBA, KOGI STATE, NIGERIA
}

\author{
${ }^{1}$ SStephen, E., Ekwetafia, B.E., Esemikose, E.E., Akogu, E.A. ${ }^{2}$ and Abioye, O.P ${ }^{3}$ \\ ${ }^{1}$ Department of Microbiology, Kogi State University, Anyingba, Kogi State, Nigeria \\ ${ }^{2}$ Department of Science Laboratory Technology, Kogi State Polytechnic Lokoja, Kogi State, Nigeria \\ ${ }^{3}$ Department of Microbiology, Federal University of Technology, Minna, Niger State, Nigeria \\ *Corresponding author : psychsea07@ gmail.com , +234-8036347036
}

\begin{abstract}
The microbiological and physicochemical properties of mechanic workshop polluted soil amended with $5.6 \%(\mathrm{w} / \mathrm{w})$ cowpea chaff were studied for a period of eight weeks. The results revealed an appreciable increase in the microbial population of the mechanic workshop polluted soil amended with cowpea chaff (MPSA) than unamended mechanic workshop polluted soil (MPS). The bacteria counts ranged from $3.0 \times 10^{6} \mathrm{cfu} / \mathrm{g}$ to $14.0 \times 10^{6} \mathrm{cfu} / \mathrm{g}$ for MPS, $3.0 \times 10^{6} \mathrm{cfu} / \mathrm{g}-48.0 \times 10^{6} \mathrm{cfu} / \mathrm{g}$ for MPSA and 3.0 x $10^{6} \mathrm{cfu} / \mathrm{g}-22.0 \times 10^{6} \mathrm{cfu} / \mathrm{g}$ for oil free soil (OFS) while the fungi counts ranged from $8.0 \times 10^{6} \mathrm{cfu} / \mathrm{g}$ to $15.0 \times 10^{6} \mathrm{cfu} / \mathrm{g}$ for MPS, $8.0 \times 10^{6} \mathrm{cfu} / \mathrm{g}-22.0 \times 10^{6} \mathrm{cfu} / \mathrm{g}$ for MPSA and $2.0 \times 10^{6} \mathrm{cfu} / \mathrm{g}-21.0 \times 10^{6} \mathrm{cfu} / \mathrm{g}$ for OFS. There were significant differences at $5 \%$ probability levels in both bacteria and fungi counts. Higher $\mathrm{pH}$, moisture contents, electrical conductivity and phosphorus concentration were observed in MPSA compared to MPS and OFS. Significant differences exist in the $\mathrm{pH}$, moisture contents and nitrogen concentration at $5 \%$ probability levels. However, no significant differences ( $>0.05$ ) were observed in the electrical conductivity, phosphorus, organic carbon and organic matter contents of the soils. The results suggest that cowpea chaff could be used as biostimulating agent in reclaiming mechanic workshop polluted soil.
\end{abstract}

(Keywords: mechanic workshop polluted soil, cowpea chaff, biostimulating agent, physicochemical properties)

\section{INTRODUCTION}

An important source of petroleum contamination in Nigeria that has attracted little public awareness is the indiscriminate discharge of used oil on the soil especially in mechanic workshops (1).

Environmental pollution with petroleum and petroleum products (complex mixtures of hydrocarbons) has been recognised as a serious problem especially when associated with accidental spills on large scale (2). Oil spills has been a major issue across decades. One of the silent oil spills in Nigeria which goes unnoticed is the pollution in the mechanic workshops where used oil and fuels are often released to the environment causing pollution. Used oil can be considered as one of the sources responsible for polluting the soil with hydrocarbons (3). Used motor oil has higher concentration of PAHs than unused motor oil. It consists of alkanes, cycloalkaanes and linear alkanes (4). Presence of used oil, regardless of their sizes is potentially dangerous to the soil microflora and fauna and can have detrimental effect on the ecosystem. When rain falls, pollutants in mechanic workshop soils are washed off the soil into neighbouring soil which results in soil enrichment as well as underground water pollution. It causes distortion of the soil and result in wastage of land as no economic activity can be carried on it. Petroleum products such as engine lubricants, petrol and diesel are used daily in various forms in mechanic workshops. These products tend to harden and changed the colour of the soil which may have untold health hazards on the artisans (5). Due to the hardened surfaces and blackish colouration of the soil, there is the need to reclaim such workshops especially the abandoned ones for agricultural or commercial purposes. Hence, the need for cheap and readily available materials to amend and enhance the rate of biodegradation of the mechanic workshop polluted soil without distorting the biological, chemical and physical properties of the soil. Cowpea chaff is an organic waste product that is obtained after harvesting and processing the cowpea. It is often dumped and burn in the farm or used as fodder for livestock in the dry season. 
Cowpea is widely grown in Nigeria, hence its ready availability. This study therefore was undertaken to assess the suitability of using cowpea chaff which is cheaper than inorganic fertilizer to reclaim the mechanic workshop polluted soil in Anyingba.

\section{MATERIAL AND METHODS}

\section{Study area description}

The experiment was conducted in the botanical garden of the Kogi State University, Anyingba, Nigeria. Anyingba lies between latitudes $7^{0} 29^{1}$ North and longitude $7^{0} 11^{1}$ East and falls within the rain forest belt of Nigeria with an annual mean rainfall of about $1600 \mathrm{~mm}$. The average temperature of the experimental area is $25^{\circ} \mathrm{C}(6)$.

\section{Sample collection}

Soil samples were collected from mechanic workshop soil opposite First City Monument Bank in Anyingba and from composite soil opposite the mechanic workshop free from oil which served as control. $9 \mathrm{~kg}$ of oil free soil (OFS), mechanic workshop polluted soil (MPS) and mechanic workshop polluted soil amended with cowpea chaff (MPSA) were transferred to six perforated earthenware pots. MPSA was amended with $500 \mathrm{~g}$ of ground cowpea chaff to achieve $5.6 \%$ amendment level. Two of the pots contained oil free soil (OFS). Another two contained mechanic workshop polluted soil without amendment (MPS) while the last two contained mechanic workshop polluted soil amended with cowpea chaff (MPSA). The pots were exposed in the Botanical garden of Kogi State University, Anyingba, Nigeria. Samples were collected bi-weekly for a period of 8 weeks in the rainy season (May-June).

\section{Laboratory/ statistical methods}

$\mathrm{pH}$ of the soil was determined at ambient temperature using glass electrode $\mathrm{pH}$ and conductivity meter (Hannia, Italy) in 1:1 water to soil ratio. Nitrogen was determined by the micro Kjedahl method (7). Phosphorus was determined by the Murphy and Riley (8) method. The ignition method of Akinsanmi (9) was used to determine the organic matter content while the dry weight (10) was used to determine the moisture content. Microbiological analysis was carried out following the procedure described by Harrigan and McCane (11). Descriptive statistics and analysis of variance (ANOVA) was performed using procedure of SPSS version 16 (2007). Experimental precision achieved was reported at $\mathrm{p} \leq 0.05$ level.

\section{RESULTS}

Figure 1 shows the total heterotrophic bacteria counts obtained from the mechanic workshop soil (MPS), mechanic workshop polluted soil amended with cowpea chaff (MPSA) and oil free soil (OFS) within 8 weeks. The counts ranged from $3.0 \times 10^{6} \mathrm{cfu} / \mathrm{g}$ to $14.0 \times 10^{6} \mathrm{cfu} / \mathrm{g}$ for MPS, $3.0 \times 10^{6} \mathrm{cfu} / \mathrm{g}-48.0 \times 10^{6} \mathrm{cfu} / \mathrm{g}$ for MPSA and $3.0 \times 10^{6} \mathrm{cfu} / \mathrm{g}-22.0 \times 10^{6} \mathrm{cfu} / \mathrm{g}$ for OFS. There was an appreciable increase in counts of OFS and MPSA compared to MPS. Significant differences exist at 5\% probability levels between MPS, MPSA and OFS.

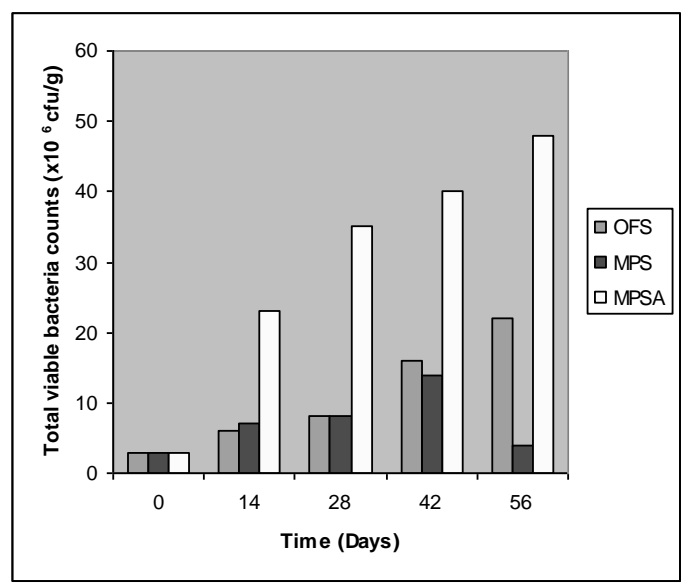

Figure 1 Total viable bacteria count in soil samples

OFS: oil free soil, MPS: Mechanic workshop polluted soil, MPSA: Mechanic workshop polluted soil amended with cowpea chaff

Figure 2 shows the fungal counts obtained from the soil samples. The counts ranged from $8.0 \mathrm{x}$ $10^{6} \mathrm{cfu} / \mathrm{g}$ to $15.0 \times 10^{6} \mathrm{cfu} / \mathrm{g}$ for MPS, $8.0 \times 10^{6}$ $\mathrm{cfu} / \mathrm{g}-22.0 \times 10^{6} \mathrm{cfu} / \mathrm{g}$ for MPSA and $2.0 \times 10^{6}$ $\mathrm{cfu} / \mathrm{g}-21.0 \times 10^{6} \mathrm{cfu} / \mathrm{g}$ for OFS. The highest fungi count was observed in MPSA. Significant differences exist $(\mathrm{p}<0.05)$ between the soil samples analysed. 


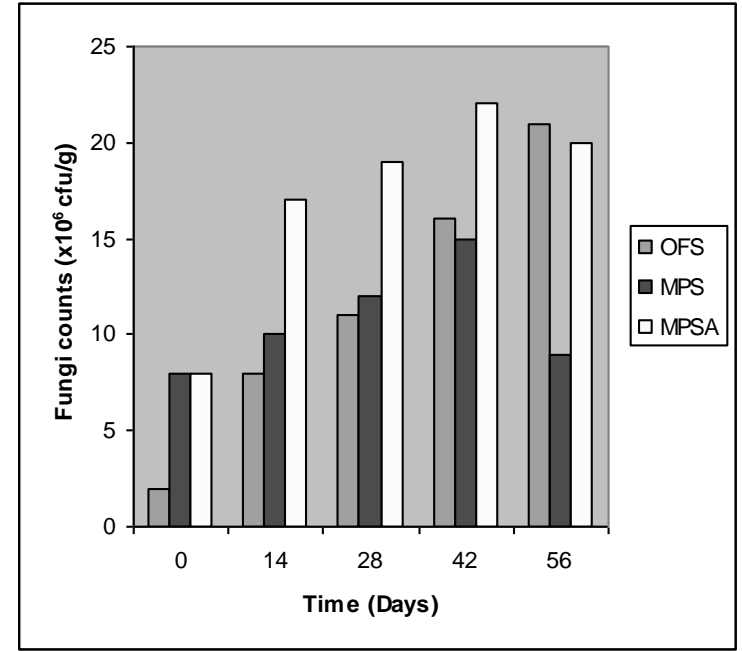

Figure 2: Fungi counts in soil samples analysed OFS: oil free soil, MPS: Mechanic workshop polluted soil, MPSA: Mechanic workshop polluted soil amended with cowpea chaff

Table 1: Frequency and occurrence of microorganisms in soil samples analysed

\begin{tabular}{lccccc}
\hline Isolates & OFS & MPS & MPSA & Total & Percentage \\
\hline $\begin{array}{l}\text { Aspergillus } \\
\text { flavus }\end{array}$ & 3 & 1 & 3 & 7 & 6.98 \\
A. fumigatus & 2 & 1 & 2 & 5 & 4.95 \\
A. niger & 3 & 3 & 2 & 8 & 7.95 \\
$\begin{array}{l}\text { Bacillus spp } \\
\text { Candida spp }\end{array}$ & 4 & 3 & 6 & 13 & 12.87 \\
$\begin{array}{l}\text { Escherichia } \\
\text { coli }\end{array}$ & 3 & 0 & 0 & 3 & 6.93 \\
Microccoccus & 3 & 3 & 4 & 10 & 9.97 \\
spp & & & & & \\
$\begin{array}{l}\text { Mucor spp } \\
\text { Penicillum }\end{array}$ & 2 & 2 & 3 & 7 & 6.93 \\
spp & 3 & 3 & 3 & 9 & 8.91 \\
$\begin{array}{l}\text { Proteus spp } \\
\text { Pseudomonas }\end{array}$ & 2 & 1 & 2 & 5 & 4.95 \\
spp & 2 & 4 & 5 & 11 & 10.89 \\
$\begin{array}{l}\text { Pythium spp } \\
\text { Rhizopus spp }\end{array}$ & 0 & 2 & 2 & 4 & 3.96 \\
Staphylococcu & 2 & 1 & 2 & 7 & 6.93 \\
spp & & & 2 & 5 & 4.95 \\
\hline Total & & & & 101 & $\approx 100$ \\
\hline
\end{tabular}

OFS: Oil free soil, MPS: Mechanic workshop polluted soil, MPSA: Mechanic workshop polluted soil amended with cowpea chaff
Table 1 show the frequency and occurrence of organisms isolated from MPS, MPSA and OFS. Bacillus spp had the highest frequency of occurrence with $12.87 \%$ followed by Pseudomonas spp (10.89\%) and Micrococcus spp $(9.9 \%)$. The least frequency of occurrence was observed in Escherichia coli (2.97\%).

Table 2 show the mean physicochemical characteristics of the soil samples. The $\mathrm{pH}$ tends towards neutrality. The least $\mathrm{pH}(6.32 \pm 0.08)$ was observed in MPS while the highest value was observed in OFS. There were significant differences $(\mathrm{p}<0.05)$ between the soil samples.

The highest moisture content was observed in MPSA $(20.36 \pm 4.20 \%)$. The moisture content ranged from $8.70 \pm 1.41 \%$ to $20.36 \pm 4.20 \%$. Significant differences exist in the moisture contents of the soil samples at 5\% probability.

The electrical conductivity increased gradually from OFS to MPSA. The electrical conductivity ranged from $0.16 \pm 0.05 \mathrm{uS} / \mathrm{cm}$ to $0.38 \pm 0.09$ $\mathrm{uS} / \mathrm{cm}$. There were no significant differences ( $>0.05)$ between the soil samples.

The phosphorus concentration in OFS, MPS and MPSA were low. It ranged from $5.83 \pm 0.64 \mathrm{ppm}$ to $8.13 \pm 1.67 \mathrm{ppm}$. The least concentration was observed in MPS while MPSA had the highest concentration. There were no significant differences ( $>0.05)$ between the soil samples.

The organic carbon and organic matter contents were higher in MPS and MPSA than OFS. The organic carbon ranged from $1.04 \pm 0.04 \%$ to $1.46 \pm 0.30 \%$ while the organic matter content ranged from $1.79 \pm 0.07 \%-2.52 \pm 0.50 \%$. There were no significant differences ( $>0.05)$ in both organic carbon and organic matter contents between the soil samples.

The nitrogen content in the soil samples was low. The least nitrogen was observed in OFS while MPS had the highest content. There were significant differences $(p<0.05)$ in the nitrogen contents between the soil samples. 
Table 2: Physicochemical characteristics of soil sample analysed (mean \pm standard error of mean).

\begin{tabular}{lccc}
\hline & OFS & MPS & MPSA \\
\hline pH & $7.26 \pm 0.13^{\mathrm{a}}$ & $6.32 \pm 0.08^{\mathrm{ab}}$ & $6.88 \pm 0.32^{\mathrm{b}}$ \\
MOIST (\%) & $12.34 \pm 2.69^{\mathrm{c}}$ & $8.70 \pm 1.41^{\mathrm{b}}$ & $20.36 \pm 4.20^{\mathrm{a}}$ \\
E.C (uS/cm) & $0.16 \pm 0.05$ & $0.23 \pm 0.06$ & $0.38 \pm 0.09$ \\
Phosp (ppm) & $7.39 \pm 0.43$ & $5.38 \pm 0.64$ & $8.13 \pm 1.67$ \\
O.M.C (\%) & $1.79 \pm 0.07$ & $2.52 \pm 0.50$ & $2.48 \pm 0.59$ \\
O.C (\%) & $1.04 \pm 0.04$ & $1.46 \pm 0.30$ & $1.44 \pm 0.34$ \\
$\mathrm{~N}(\%)$ & $0.23 \pm 0.01^{\mathrm{a}}$ & $0.39 \pm 0.12^{\mathrm{b}}$ & $0.32 \pm 0.08^{\mathrm{b}}$ \\
\hline
\end{tabular}

a,b,c : means denoted by different superscripts along the same column are significantly $(\mathrm{p}<0.05)$ different. OFS: oil free soil, MPS: Mechanic workshop polluted soil, MPSA: Mechanic workshop polluted soil amended with cowpea chaff, E.C : Electrical conductivity, Phosp: Phosphorus Moist: moisture, O.C: organic carbon, O.M.C: Organic matter content, N: Nitrogen.

\section{DISCUSSION}

Microbiological results revealed higher bacteria and fungi counts in MPSA and OFS compared to MPS. The higher counts observed in MPSA could be attributed to the introduction of the cowpea chaff which has improved the soil properties. This findings is in agreement with similar work by Akpoveta et al.(12). The higher counts in OFS relative to MPS may be due to the absence of petroleum products (petrol, diesel, engine lubricants). It could also be an indication of the inability of microbes to survive the presence of high oil concentration in the mechanic polluted soil environment (13). These results also affirm other findings that microbial populations in hydrocarbon polluted soil were usually low $(2,6,14)$. The microorganisms consistently isolated were Bacillus spp, Pseudomonas spp, Proteus spp, Micrococcus spp, Escherichia coli, Staphylococcus spp, Aspergillus flavus, A. fumigatus, A. niger, Candida spp, Mucor spp, Penicillium spp, Pythium spp and Rhizopus spp. These organisms have been reported by many authors including Ijah et al. (15), Okereke et al. (14), Chikere et al. (16), Stephen et al. (3) and Stephen and Egene (6) to play active roles in the breakdown of hydrocarbons. Ijah et al. (15) are of the view that Bacillus spp, Pseudomonas spp, Micrococcus spp presences in soil samples polluted by hydrocarbons may be due to their effective degradative enzyme systems and their ability to adapt to the environment. Aspergillus spp, especially $A$. niger and A. flavus have been reported to be capable of initiating the degradation of $\mathrm{n}$-alkanes present in hydrocarbons by sub-terminal oxidation (18).

The $\mathrm{pH}$ in MPSA was higher than in MPS. This is an indication of increased metabolic activities as a result of the amendment in MPSA while the low $\mathrm{pH}$ recorded in MPS implied decreased acidity resulting from less metabolic activities by soil organisms and the fact that oil contains many free cations, causing them to have properties of weak acid (12).

The moisture content in MPS was lower than OFS and MPS. This could be due to the oil barrier and compact nature of the soil as a result of the prolonged pollution in the mechanic workshop preventing water from percolating through the soil while the high moisture content observed in MPSA could be due to the improved physical properties of the soil as a result of the amendment

The higher electrical conductivity observed in MPSA compared to MPS and OFS may be due to the bioremediation process resulting in the release of salts and ions from the oil polluted soil. The low electrical conductivity in OFS may be attributed to low ions and salts as a result of the absences of weathering hydrocarbons in the soil.

The phosphorus concentration was higher in MPSA than OFS and MPS. This may be due to higher organic matter contents of the soil as a result of the cowpea chaff amendment. It could also be due to the existence of reduced condition in the soil that made iron phosphorus soluble and brought some phosphorus into solution $(2,3,6)$.

The organic carbon and organic matter content were both higher in MPS than MPSA and OFS. This may be due to the slow rate of degradation in MPS compared to the oil free soil and the amended soil. The lower organic carbon and organic matter contents in MPSA may be due to the stimulation of microbial metabolism by cowpea chaff. 
The higher values of nitrogen observed in MPS may be due to the fact that petroleum products contain varying properties of nitrogen substances (18) while the low value observed MPSA compared to MPS may be due to increased metabolism of the petroleum products in the soil as a result of biostimulation of the soil microbiota using the chaff.

\section{CONCLUSION}

The result of the study revealed higher $\mathrm{pH}$, moisture content, electrical conductivity, phosphorus and lower organic carbon and organic matter content in mechanic workshop polluted soil amended with cowpea chaff than unamended mechanic workshop polluted soil. This suggests that waste organic material such as cowpea chaff possess the potential to reclaim mechanic workshop polluted soil and should be employed in reclaiming abandoned mechanic workshop soils.

\section{REFERENCES}

1. Amund, O.O., Omole, A.C., Esiobu,N. and Ugoji, O.E.(1993). Effect of waste engine oil spillage on soil physicochemical and microbiological properties. Journal of Science and Resource Development, 1(1), 61-64.

2. Ijah, U.J.J. and Abioye, O.P. (2003). Assessment of physicochemical and Microbiological Properties of soil 30 months after kerosene spill. Journal of Research in Science and Management, 1(1), 24-30.

3. Stephen, E., Okolo, M.O. and Akogu, E.A. (2011). Microbiological properties of oil impacted soil 36 months after diesel spill. International Journal of Education, Science, Mathematics and Environmental Studies, 3(1), 77-82.

4. Doe, A. (1989). Mineral-based crankcase oil. In: The Installation, Restoration programme and Toxicological Guide. Vol .4. WrightPaterson Air Force Base. Interagency Agreement. No. 1891.A076-A1

5. Bossert, I. and Bartha, R. (1994). The fate of petroleum in soil ecosystem. In :
Petroleum Microbiology, Macmillan, New York, U.S.A, pp 435-473.

6. Stephen, E. and Egene, U.M. (2012). Microbiology and physicochemical properties of soil polluted with lubricating oil in Anyingba, Kogi State, Nigeria. Nigerian Journal of Technological Research, 7(2), 49-52.

7. Ibitoye, A.A. (2006). Laboratory Manual on Basic Soil Analysis (2 ${ }^{\text {nd }}$ ed). Foladave Nigeria Limited, Akure, pp 30-37.

8. Murphy, J. and Riley, J.P. (1962). A modified Single Sowton method for the determination of phosphorus in natural water. Analytical Chemistry, 27, 31-36.

9. Akinsanmi, O. (1975). Certificate Agricultural Science. Longman, Nigeria. Pp 104-112.

10. Tropical Development Institute, TDI. (1984). Outlined method for the determination of organic matter content.

11. Harrigan, W.F. and McCane, M.E.(1990). Laboratory methods in Food and Dairy Microbiology, $8^{\text {th }}$ ed.Academic press, London

12. Akpoveta, O.V., Egharevba, F., Medjor, O.W., Osaro, K.I. and Enyemike, E.D. (2011). Microbial degradation and its kinetics on crude oil polluted soil. Research Journal of Chemical Sciences, 1 (16), 8-14.

13. Antai, S.P.(1990). Biodegradation of Bonny light crude oil by Bacillus spp and Pseudomonas spp. Waste management, 10, 61-64.

14. Okereke, J.N., Obiekezie, S.O. and Obasi, K.O.(2007). Microbial flora of oil spilled sites in Egbema, Imo State, Nigeria. African Journal of Biotechnology, 6(4), 991-993.

15. Ijah, U.J.J., Tambaya, K. and Uwabujo, A.E. (2002). The fate of spilled kerosene in the soil: a case study of kerosene spillage in Maikunkele, Niger State, Nigeria. Journal of Nigerian 
Association of Teachers of Technology, 3(10), 275-283.

16. Chikere, C.B., Okpokwasili, G.C. and Chikere, B.O. (2009). Bacterial diversity in a tropical oil polluted soil undergoing bioremediation. African Journal of Biotechnology, 8(11), 25352540.

17. Watkinson, R.J. and Morgan, P. (1990). Physiology of Aliphatic hydrocarbondegrading microorganisms. Biodegradation, 1, 79-92.

18. Ayotamuno, M.J., Kogbara, R.B. and Egwuenum, P.N. (2006). Comparism of corn and elephant grass in the phytoremediation of a petroleum hydrocarbon contaminated agricultural soil in Port-Harcourt, Nigeria. Journal of Agriculture and Environment, 4 (2\&4), 218-222. 